\title{
Tangible economic value of non-timber forest products from peat swamp forest in Kampar, Indonesia
}

\author{
BINTANG C.H. SIMANGUNSONG ${ }^{1, \boldsymbol{v}}$, ELISA G.T. MANURUNG ${ }^{1}$, ELIAS ELIAS ${ }^{2}$, \\ MANUNTUN P. HUTAGAOL ${ }^{3}$, JUSUPTA TARIGAN ${ }^{4}$, SIGIT B. PRABAWA \\ ${ }^{1}$ Department of Forest Products, Faculty of Forestry and Environment, Institut Pertanian Bogor. Jl. Ulin, IPB University Campus, Dramaga, Bogor \\ 16680, West Java, Indonesia. Tel.: +62-251-862-1677, Fax.: +62-251-862-1256, "email: bintangcsimangunsong@gmail.com \\ ${ }^{2}$ Department of Forest Management, Faculty of Forestry and Environment, Institut Pertanian Bogor. Jl. Ulin, IPB University Campus, Dramaga, Bogor \\ 16680, West Java, Indonesia \\ ${ }^{3}$ Department of Economics, Faculty of Economics and Management, Institut Pertanian Bogor. Jl. Agatis, IPB University Campus, Dramaga, Bogor \\ 16680, West Java, Indonesia \\ ${ }^{4}$ Non Timber Forest Products-Exchange Programme Indonesia. Jl. Puspa Sari, Blok W6 No. 1/I, Taman Cimanggu, Bogor 16164, Bogor, West Java, Indonesia \\ ${ }^{5}$ Environment and Forestry Research and Development Institute of Kupang. Jl. Alfons Nisnoni No. 7, Airnona, Kupang 85228, East Nusa Tenggara, Indonesia
}

Manuscript received: 25 November 2020. Revision accepted: 30 November 2020.

\begin{abstract}
Simangunsong BCH, Manurung EGT, Elias, Hutagaol MP, Tarigan J, Prabawa SB. 2020. Tangible economic value of nontimber forest products from peat swamp forest in Kampar, Indonesia. Biodiversitas 21: 5954-5960. Development of alternative economy based on non-timber forest products usage is an important means to prevent forest conversion and preserve the quality of a forest ecosystem. The main objectives of this study were to identify and calculate the economic value from tangible/marketable perspective of the non-timber forest products (NTFPs) provided by peat swamp forest in Kampar, Sumatra, Indonesia. This is one of the largest remaining peat swamp forest ecosystems in the country. Seven villages located around that forest ecosystem with total forest cover area of 201,224 ha were chosen as samples. A conversion return approach was used to estimate the economic value of non-timber forest products. The results showed 18 kinds of non-timber forest products were identified, but only seven were used commercially by community. They are jungle rubber (Hevea brasiliensis), sago (Metroxylon sp.), swiftlet nest (Aerodramus fuciphagus), honey, betel nut (Areca catechu), Agathis resin (Agathis dammara), and pandan (Pandanus amaryllifolius Roxb.) The obtained economic value of NTFPs was very low, which was about Rp 9,367.4 (or US\$0.68 ha-1 $\mathrm{yr}^{-1}$ ). Market development of non-timber forest products is then crucial, and the government should play an important role in promoting it in collaboration with private companies. Non-marketed nontimber forest products and various environmental services should also be taken into account to measure that peat swamp forest ecosystem value. Otherwise, concerns about the sustainability of that forest ecosystem in Indonesia due to undervaluation of forest resources will continue.
\end{abstract}

Keywords: Farmgate price, forest conversion, NTFPs, peat swamp forest, valuation

\section{INTRODUCTION}

Indonesia has the largest tropical peatland in the world with total peat swamp forest areas of about 15 million ha. To put into perspective, the size of peatland in Indonesia is almost twice of peatland in the Democratic Republic of Congo that ranks second with 9 million ha, and three times of peatland in the Republic of Congo, which ranks third with 5.5 million ha (Ministry of Environment and Forestry Republic of Indonesia 2018). Peat swamp forest in Indonesia covers $12 \%$ of Indonesia's forestland, and spreads across Sumatra, Kalimantan, Sulawesi, and Papua.

One of Indonesia's largest peat swamp forest ecosystems is found in the Kampar Peninsula, Sumatra (Tropenbos Indonesia 2010). This ecosystem has a total area of around 671,125 ha and is located between two major rivers (i.e., the Siak river and the Kampar River), and two districts (i.e., the District of Siak and the District of Pelalawan). About $40 \%$ of this area is still in good condition, especially in the center, which consists of four protected areas in the form of lakes whose existences depend on $60 \%$ of the peat swamp forest area around it.
This peat swamp forest ecosystem has two peat domes with a depth of at least $16 \mathrm{~m}$ each, which have important roles to preserve the watershed system in that area and to store a very large carbon. It is also a habitat for Sumatran tiger and several endangered species as well as a hunting area of the indigenous Akit tribe. Its lakes and rivers are sources of drinkable and clean water and for fishermen's livelihood. Its forest resources, such as non-timber forest products (NTFPs), have been used as traditional medicines, foods, raw materials, and other usages. Moreover, this forest ecosystem area is also an economical source for rubber, sago palm, rice, corn, and coconut farmings.

However, since the year 2000, the peat swamp forests have been deforested, degraded, and disturbed by fires as the impacts of conversion into industrial forest plantations and large-scale oil palm plantation estates (Yayasan Mitra Insani 2008; Tropenbos Indonesia 2010). This forest ecosystem is also under threat from the development of community plantations as one of options to improve the prosperity of local people who live in poor villages in the Kampar Peninsula. Those forest deforestation and degradation would link to a reduction of NTFPs 
production, and as a consequence, the proportion of NTFPs contributing to dietary intake and household cash income would be reduced, which in turn would put local people away from their traditional livelihood (Ndangalasi et al. 2007; Gillet et al. 2016).

In contrast, many studies found the important contribution of NTFPs on income of households dwelling in and on the fringe of forest such as in Africa (Heubach et al. 2011; Schaafsma et al. 2014), Asia (Mahapatra and Tewari 2005; Delang 2006; Ghate et al. 2009; Saha and Sundriyal 2012; Dash et al. 2016), Latin-America (Godoy et al. 2002; Shone and Caviglia-Harris 2006; Guariguata et al. 2008), in less developed countries (Stanley et al. 2012), and global (Guariguata et al. 2010; Angelsen et al. 2014; Dawson et al. 2014). Such findings have been acknowledged by the government of Indonesia since 2008 with the issuance of a decree of Minister of Forestry No. 49 Year 2008 on forest village, which gives people who dwell in the fringe of forest access to manage forest as legally as big companies.

It is obvious that many people largely depend on the natural existence and stability of the peat swamp forest ecosystem in the Kampar Peninsula. Development of alternative economy based on NTFPs usage is, therefore, an important means to prevent forest conversion and preserve the quality of that forest ecosystem. Thus, the main objectives of this study were to identify and calculate the economic value of the NTFPs provided by the peat swamp forest ecosystem in the Kampar Peninsula.

\section{MATERIALS AND METHODS}

\section{Study area}

This study was conducted in tropical peat swamp forest ecosystems in the Kampar Peninsula, Riau Province (Sumatra), Indonesia (Figure 1). This ecosystem has a total area of 671,125 ha and is located between longitude $\mathrm{E}$ $101^{\circ} 50^{\prime}$ to $103^{\circ} 07^{\prime}$ and latitude $\mathrm{S} 0^{\circ} 10^{\prime}$ to $1^{\circ} 14^{\prime}$. Seven villages located around the peat swamp forest area, and in two districts (District of Siak and District of Pelalawan, Province of Riau, Indonesia) were chosen as samples (Figure 1), namely: Teluk Binjai, Teluk Meranti, Pulau Muda, Segamai, Serapung, Teluk Lanus, and Sungai Rawa/Penyengat; with total administrative area of 299,289 ha, covering total forest area of 201,224 ha.

\section{Procedures}

NTFPs include all goods of biological origin derived from forests other than wood. There are many terminologies similar to that NTFPs such as secondary forest products or special forest products or non-wood forest products (FAO 1995; Gram 2001). In this study, the context of NTFPs refers to the definition stated by the Ministry of Forestry of the Republic of Indonesia, which can be defined as forest products derived from forest other than wood, includes animals, plants and their domestication and derived products (Ministry of Forestry Decree No. 35/Menhut-II/2007).

Field surveys using questionnaires, interview, and direct observation were conducted in the sampled villages from January 2014 to April 2014, to collect data and information on NTFPs including type, use, frequency and collection method, number of labor, collection time and duration, wages, collection/harvesting cost, transportation cost, processing cost, marketing cost, and market prices. Literature reviews were also conducted as well.

This study focuses on economic valuation of identified and marketed NTFPs. Valuing non-marketed NTFPs value using variety of stated or revealed preference techniques as described in IIED (2003), Stenger et al. (2009), and Riera et al. (2012) were not conducted because the interviewed farmers, as well as the local traders, had no preferences regarding non-marketed NTFPs. In other words, they were not able to transform their preferences into monetary units.

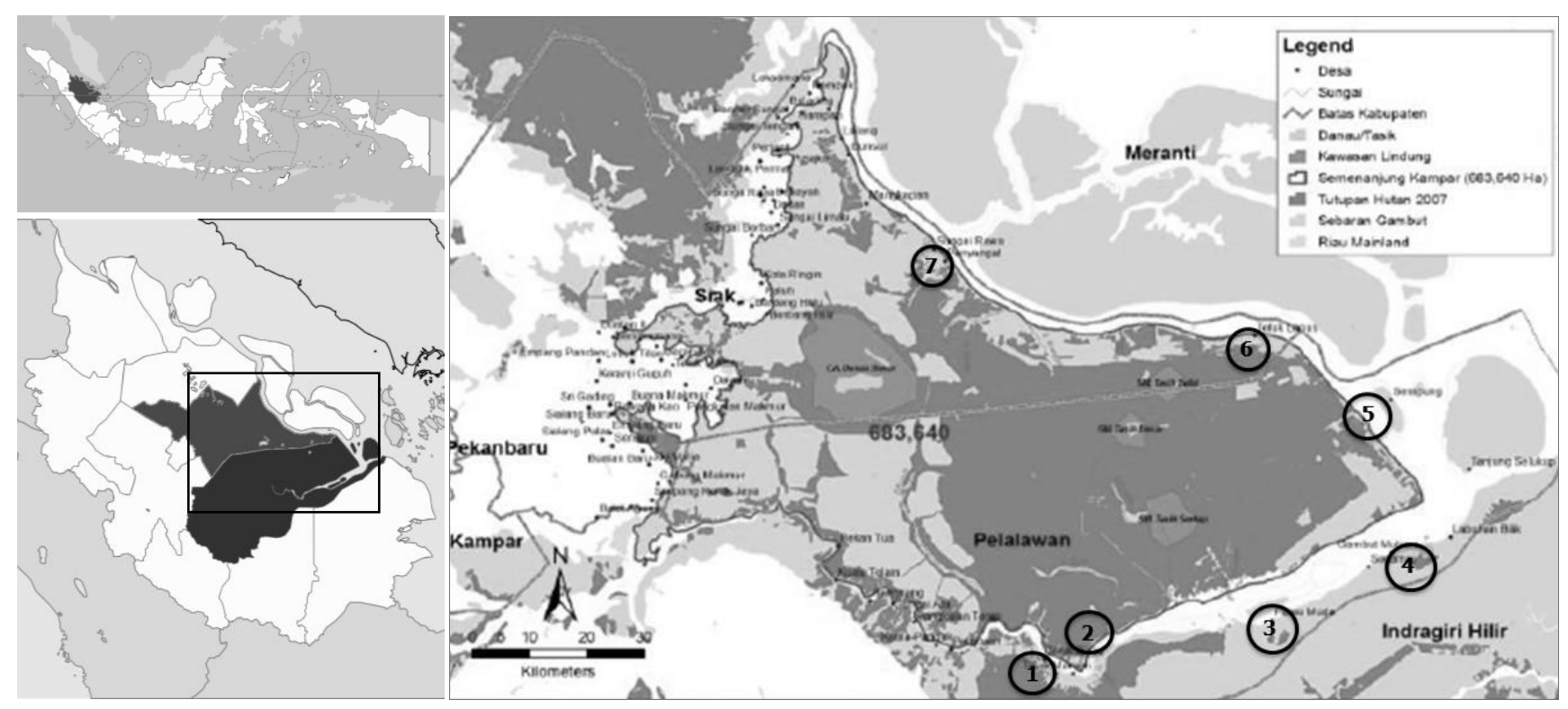

Figure 1. Map of the studied areas in tropical peat swamp forest ecosystems in the Kampar Peninsula, Riau Province, Indonesia, consisting of seven villages (circles): 1. Teluk Meranti; 2. Teluk Binjai; 3. Pulau Muda; 4. Segamai; 5. Serapung; 6. Teluk Lanus; 7. Sungai Rawa/Penyengat 


\section{Data analysis}

The relevant measure of NTFPs' economic value is the farmgate price, which is similar to the stumpage valuation as a residual value, sometimes called conversion return. That is the value of standing timber before any value added by processing. This value was estimated by subtracting total expenditure costs (collection, transportation, processing, and marketing costs and wages) and normal profit from its market price (Klemperer 1996; IIED 2003) and then adjusted with total villages' covered forest areas of 201,224 ha. The normal profit is assumed to be $25 \%$ of total expenditure costs, and the NTFP market price is an available local market price. Besides, the net income and the net present value of NTFPs were also calculated. The net income was determined by subtracting total expenditure costs from gross revenues, while the net present value was obtained by dividing the NTFPs' economic value with an interest rate when NTFPs' benefits stream is accrued in perpetuity. In this study, an interest rate was assumed to be $6 \% \mathrm{yr}^{-1}$. Due to differences in some of the data sources, all Rupiah values used for comparison were converted to constant US dollars at 2015 prices.

The technique described above has been used in several studies to estimate use values of NTFPs provided by Indonesia's tropical rain forest. Institut Pertanian Bogor (1999) used it at dry lowland and swamp forests in Jambi and Central Kalimantan provinces, Kim (2002) at dry lowland forest in East Kalimantan Province, and Bahruni et al. (2007) in the West Kalimantan province. The technique was also used to estimate the economic value of Indonesia's production forest (Simangunsong 2003) and of Indonesia's forest biomass as feedstock for bioenergy (Simangunsong et al. 2017).

\section{RESULTS AND DISCUSSION}

\section{Results}

Most local people in the Kampar Peninsula, Riau Province, Indonesia live in poor villages. Their subsistence needs were obtained from economic activities, including food plantations, forest products collection, fishery, water transportation service, and staple goods trade. So far, their economic activities were still supportive of the existence of the peat swamp forest ecosystem. This is indicated by the fact that the water level of the peat swamp forest ecosystem was still maintained, and not decreased as commonly occurred in degraded peatlands.

Regarding NTFPs utilization, local people who live in the villages in the Kampar Peninsula were not able so far to optimally use these NTFPs provided by the peat swamp forest to raise their cash income subsistence living. This statement is indicated by the fact that a variety of NTFPs was out of their attention. Based on the field surveys, interviews, and observations, as many 18 kinds of NTFPs were identified from 7 villages in the Kampar Peninsula, but only 7 kinds of NTFPs have been used commercially (Table 1). They are karet hutan (jungle rubber; Hevea brasiliensis), sagu (sago; Metroxylon sp.), sarang burung walet (swiftlet nest; Aerodramus fuciphagus), madu (honey), pinang (betel nut; Areca catechu L), kopal (Agathis resin; Agathis dammara), and pandan (Pandanus amaryllifolius Roxb.). Most identified NTFPs were not commercialized due to the lack of buyers and low local market prices.

Further, as shown in Table 2, NTFPs were important in day-to-day life of people and were used for food, spices, medicines, ornamentation, roofing materials, basket, and mat-making purposes. Those NTFPs also constituted a critical component of their food and livelihood security. NTFPs were traditionally collected by and generally provide supplementary income sources to forest fringe dwellers. But, in certain villages, it may also the main income source.

Based on NTFPs' yields, harvesting/collection costs, transportation costs, processing costs, labor wages, marketing costs, and market prices; net income, economic value, and net present value of each identified and marketed NTFP were estimated and shown by type in Table 3 and by village in Table 4. Total net income, economic value and net present value of NTFPs were, respectively, Rp 1,908.8 millions $\mathrm{yr}^{-1}$, Rp 9,367.4 $\mathrm{ha}^{-1} \mathrm{yr}^{-1}$, and $\mathrm{Rp} 156,123.4 \mathrm{ha}^{-1}$. These economic and net present values were obtained after weighting by villages' total covered forest area of 201,224 ha. Table 3 shows the largest share of the NTFPs value comes from swiftlet nest (90\%), followed by jungle rubber $(5 \%)$ and sago $(4 \%)$. The other four NTFPs all together accounted for $1 \%$ of the NTFPs value. Table 4 shows only 2 villages had significantly used NTFPs. They were Teluk Binjai (46\%) and Teluk Meranti (50\%). The other villages were hardly used those NTFPs.

\section{Discussion}

This study confirmed that the peat swamp forest in the Kampar Peninsula, Riau Province, Indonesia has a great potential for NTFPs. However, the obtained NTFPs economic value of Rp 9,367.4 (or US\$0.68 $\mathrm{ha}^{-1} \mathrm{yr}^{-1}$ ) was very small when compared with NTFPs economic values from dry lowland primary forest of Rp 333,828 (or US\$76.09 $\mathrm{ha}^{-1} \mathrm{yr}^{-1}$ ) or dry lowland logged-over area of Rp. 268,610 (or US\$61.22 ha $^{-1} \mathrm{yr}^{-1}$ ) in East Kalimantan (Kim, 2002). It is also lower than the average NTFPs value from swamp forests in Jambi and Central Kalimantan provinces of Rp. 31,717 (or US\$10.54 ha-1 $\mathrm{yr}^{-1}$ ) (Institut Pertanian Bogor 1999). These figures' differences are likely due to the differences in forest type and condition, research location, and number and types of usage NTFPs.

The obtained NTFPs' economic value was very low since only seven out of 18 NTFPs were used commercially and the other NTFPs were used just for subsistence needs. Local residents had not made the other eleven NTFPs a good source of their family income because the current market condition of NTFPs in this region is not so promising, caused by the very low demand. As in economic principle, weak demand normally leads to low prices too. Thus, both the demand and price are not conducive for their commercial production. The problem of 
commercialization of NTPFs in this region is not limited to those eleven products. Except for swiftlet nests, local market for NTPFs tends to be oligopsonistic where the buyers have better position in determining price since their number much smaller than the sellers. A major disadvantage of paying producers with low prices for their NTFPs is that it does not provide any incentive to implement any measure for conservation of NTFPs production capacity.

Table 1. Identified NTFPs in the Kampar Peninsula (Riau Province, Indonesia) by village

\begin{tabular}{|c|c|c|c|c|c|c|c|}
\hline \multirow{2}{*}{ NTFPs Type } & \multicolumn{7}{|c|}{ Village } \\
\hline & TB & TM & PM & SG & SR & TL & SP \\
\hline Akar kuning (Arcangelisia flava) & $\sqrt{ }$ & $\sqrt{ }$ & $\sqrt{ }$ & $\sqrt{ }$ & $\sqrt{ }$ & & $\sqrt{ }$ \\
\hline Ampelam babi (Mangifera havilandii) & $\sqrt{ }$ & $\sqrt{ }$ & $\sqrt{ }$ & $\sqrt{ }$ & $\sqrt{ }$ & & $\sqrt{ }$ \\
\hline Anggrek-anggrek (Orchidaceae) & & $\sqrt{ }$ & & $\sqrt{ }$ & $\sqrt{ }$ & & \\
\hline Asam kandis (Eleiodoxa conferta) & $\sqrt{ }$ & $\sqrt{ }$ & $\sqrt{ }$ & $\sqrt{ }$ & $\sqrt{ }$ & & $\sqrt{ }$ \\
\hline Betel nut (Areca catechu $\mathrm{L})$ & + & $\sqrt{ }$ & + & $\sqrt{ }$ & $\sqrt{ }$ & + & \\
\hline Agathis resin (Agathis dammara) & $\sqrt{ }$ & $\sqrt{ }$ & $\sqrt{ }$ & + & $\sqrt{ }$ & + & $\sqrt{ }$ \\
\hline Alstonia resin (Alstonia spp) & & & & & & + & \\
\hline Kantong semar (Nepenthes sp) & $\sqrt{ }$ & $\sqrt{ }$ & $\sqrt{ }$ & $\sqrt{ }$ & $\sqrt{ }$ & & $\sqrt{ }$ \\
\hline Karamunting (Rhodomyrtus tomentosa) & & & & & & & $\sqrt{ }$ \\
\hline Jungle rubber (Hevea brasiliensis) & + & + & & & & & $\sqrt{ }$ \\
\hline Kulit medang (Alseodaphne sp) & $\sqrt{ }$ & $\sqrt{ }$ & $\sqrt{ }$ & $\sqrt{ }$ & $\sqrt{ }$ & & $\sqrt{ }$ \\
\hline Madu (Honey) & & + & $\sqrt{ }$ & $\sqrt{ }$ & $\sqrt{ }$ & & \\
\hline Nipah (Nypa fruticans) & & & $\sqrt{ }$ & $\sqrt{ }$ & $\sqrt{ }$ & & $\sqrt{ }$ \\
\hline Palem merah (Cyrtostachys lakka) & $\sqrt{ }$ & $\sqrt{ }$ & $\sqrt{ }$ & $\sqrt{ }$ & $\sqrt{ }$ & & $\sqrt{ }$ \\
\hline Pandan (Pandanus amaryllifolius Roxb.) & $\sqrt{ }$ & $\sqrt{ }$ & $\sqrt{ }$ & + & $\sqrt{ }$ & & $\sqrt{ }$ \\
\hline Rattan (Calamus spp) & $\sqrt{ }$ & $\sqrt{ }$ & $\sqrt{ }$ & $\sqrt{ }$ & $\sqrt{ }$ & & $\sqrt{ }$ \\
\hline Sago (Metroxylon sp) & $\sqrt{ }$ & & + & & + & & + \\
\hline Swiftlet nest (Aerodramus fuciphagus) & + & + & & & & & \\
\hline
\end{tabular}

Notes: $\sqrt{ }$ Identified but not yet commercially used; + Identified and has been commercially used; Teluk Binjai (TB), Teluk Meranti (TM), Pulau Muda (PM), Segamai (SG), Serapung (SR), Teluk Lanus (TL), and Sungai Rawa/Penyengat (SP)

Table 2. NTFPs usage by local community in the Kampar Peninsula, Riau Province, Indonesia

\begin{tabular}{|c|c|}
\hline NTFPs type & Usage \\
\hline Akar kuning & Potensial medicine for lever diseases \\
\hline Ampelam babi & Fruits \\
\hline $\begin{array}{l}\text { Anggrek- } \\
\text { anggrek }\end{array}$ & $\begin{array}{l}\text { Decoration plants; medicines for many kinds } \\
\text { of diseases such as stomach-ache, intestinal } \\
\text { tuberculosis, diarrhea, and dysentery; herbal } \\
\text { drinks; and tonic }\end{array}$ \\
\hline Asam kandis & Foods \\
\hline Betel nut & $\begin{array}{l}\text { Medicine for intestinal worm diseases, heartburn, } \\
\text { dyspepsia, expectorate cough, late menstruation, } \\
\text { diarrhea, beri-beri, edema, and malaria }\end{array}$ \\
\hline Agathis resin & $\begin{array}{l}\text { Dye emulsion, paint, ink, cosmetics, aromatic } \\
\text { substance for food }\end{array}$ \\
\hline Kantong semar & $\begin{array}{l}\text { Decoration plants, medicine for a cough, } \\
\text { stomach-ache, burns, eyes irritation and } \\
\text { preventing wet the bed }\end{array}$ \\
\hline Karamunting & Natural dye \\
\hline Jungle rubber & Resin \\
\hline Kulit medang & Anti-mosquitoes \\
\hline Honey & Foods \\
\hline Nipah & Roof of traditional house \\
\hline Palem merah & Foods \\
\hline Pandan & $\begin{array}{l}\text { Shampoo, appetizer, medicine for reducing } \\
\text { rheumatic pain, raw materials for plaited } \\
\text { products }\end{array}$ \\
\hline Rattan & $\begin{array}{l}\text { Raw materials for rattan furniture and plaited } \\
\text { rattan products }\end{array}$ \\
\hline Sago & Foods \\
\hline Swiftlet nest & Foods \\
\hline
\end{tabular}

Table 3. Net income, economic value and net present value of NTFPs by type

\begin{tabular}{|c|c|c|c|}
\hline NTFPs Type & $\begin{array}{c}\text { Net income } \\
\left(\mathrm{Rp} \text { million } \mathrm{yr}^{-1}\right)\end{array}$ & $\begin{array}{c}\text { Economic } \\
\text { value } \\
\left(\mathrm{Rp} \mathrm{ha}^{-1} \mathrm{yr}^{-1}\right)\end{array}$ & $\begin{array}{c}\text { Net present } \\
\text { value } \\
\left(\text { Rp ha }^{-1}\right) \\
\end{array}$ \\
\hline Jungle rubber & 86.6 & 417.1 & $6,951.2$ \\
\hline Swiftlet nest & $1,719.8$ & $8,496.7$ & $141,612.5$ \\
\hline Betel nut & 3.6 & 17.3 & 289.1 \\
\hline Honey & 19.7 & 97.2 & $1,620.3$ \\
\hline Sago & 78.0 & 333.3 & $5,554.5$ \\
\hline Agathis resin & 0.5 & 2.3 & 37.8 \\
\hline Pandan & 0.7 & 3.5 & 58.0 \\
\hline Total & $1,908.8$ & $9,367.4$ & $156,123.4$ \\
\hline
\end{tabular}

Tabel 4. Net income, economic value, and net present value of NTFPs by village

\begin{tabular}{lccl}
\hline Village & $\begin{array}{c}\text { Net income } \\
\left(\text { Rp million } \mathbf{~ r}^{-1}\right)\end{array}$ & $\begin{array}{c}\text { Economic } \\
\text { value } \\
\left(\mathbf{R p ~ h a}^{-1} \mathbf{~} \mathbf{r}^{-1}\right)\end{array}$ & $\begin{array}{c}\text { Net present } \\
\text { value } \\
\left(\mathbf{R p ~ h a}^{-1}\right)\end{array}$ \\
\hline Teluk Binjai & 882.5 & $4,353.9$ & $72,565.5$ \\
Teluk Meranti & 944.8 & $4,663.1$ & $77,719.2$ \\
Pulau Muda & 11.5 & 41.2 & 686.4 \\
Segamai & 1.0 & 4.5 & 75.4 \\
Serapung & 28.0 & 118.0 & $1,967.1$ \\
Teluk Lanus & 1.2 & 5.5 & 91.8 \\
Sungai Rawa/Penyengat & 40.0 & 181.1 & $3,018.0$ \\
Total & $1,908.8$ & $9,367.4$ & $156,123.4$ \\
\hline
\end{tabular}


Sustainable production of NTFPs is important for preventing poor residents from converting tropical peat swamp forests into plantation. This objective can be achieved only when the producers of NTFPs can obtain a sufficient amount of income from producing and selling NTFPs products continuously. Thus, a major challenge to make the utilization of NTFPs as a key to prevent the conversion of local peat swamp forest for development of plantations is the development of market for NTFPs, which would, in turn, create additional family income. A major element of this development is to expand market coverage and scale. This is important for making all kinds of NTPFs in Kampar Peninsula become economically feasible to carry on a profitable business.

To this end, the government may need to collaborate with private companies with business networks to market local NTFPs. However, those companies may not be interested in connecting their business network with local production due to technical and socio-economic constraints. The government needs to use its resources and authority to help overcome all these constraints. Such assistance is justified as the fact that this cooperation will provide some positive externality for the society in the form of maintenance of peat swamp forest, which is predicted will be gradually disappeared from the area if the market for local NTFPs is not developed. When positive externality comes out of private economic activity, it is justified for the government to offer the producers financial subsidies to encourage them to produce as much as society wants.

Structure of the market is another concern in making income obtained from production of NTFPs as a key for conservation of peat swamp forest in Kampar Peninsula. Present market structure of NTFPs does not protect the producers' economic interest. Local producers often receive a very low price for their products. This fact expresses the weakness in local market for NTPFs. This may be improved by organizing local producers into cooperatives, which can help them to improve their market bargaining power. The cooperative can be used as a bargaining tool for local producers when dealing with buyers of their products. Instead of individual bargaining, such collective bargaining will make the producers able to raise their market position to receive better price for their NTFPs.

In general, factors such as availability, market and demand, pricing, extraction, and ownership rights of NTFPs should be considered in developing strategies to assure sustainable commercial production of NTFPs (He et al. 2014; Ren et al., 2018). Factors such as institutional framework, economic characteristics (rivalry and excludability), demography and forest resources, and attitudes, values, and customs should also be considered since they will influence the development of NTFPs (Janse and Ottitsch 2005). Income patterns associated with the different household strategies should also be examined, and the livelihood benefits of different approaches should be compared to intensify NTFP production (Belcher et al. 2005; Ros-Tonen and Wiersum 2005).

With regard to NTFPs commercialization, some strategies are needed such as promoting certification of
NTFPs, encouraging cultivation, strengthening institutional support and policies to ensure equitable sharing of profits, encouraging traditional conservation and management practices, introducing better harvest and processing technology, developing enterprises, reducing storage and transportation losses, and reducing social and environmental costs (Marshall et al. 2003; Tiwari et al. 2009; Krishnakumar et al. 2014). The development of NTFPs should be integrated into the development agenda for the benefit of local communities (Shackleton and Pandey 2014), but should pay attention to the diversity in the nature, scale, and marketing of NTFPs, as well as to the diversity of local actors involved to make that integration success (Delgado et al. 2016). On the other side, some literature questions the potential contribution of NTFPs commercialization to poverty alleviation or conservation objectives (Salafsky and Wollenberg 2000; Arnold and Perez 2001; Sakai et al. 2016). Commercialization of NTFPs, especially from open access forests, will likely lead to overharvesting so that resource depletion, forest degradation, biodiversity depletion, weak customary tenure, and declining of the importance of NTFPs become common end. A potential harmful side of commercialization, the so-called poverty trap, should also be taken seriously. This is a situation where outsiders with capital to invest come in and develop NTFPs for export markets. They may restrict local people's social and economic development by distorting market forces to their advantage, for example, by imposing low price of NTFPs.

Further, since the obtained NTFPs' economic value was very low, other forest outputs such as non-marketed NTFPs and various environmental services should also be included in the measure of the economic value of this tropical peat swamp forest. Total economic valuation (TEV) approach is then recommended to be conducted as the next step of this study to give a complete picture of the value of the tropical peat swamp forest ecosystem

In summary, about 18 kinds of NTFPs were identified from the peat swamp forest ecosystems in the Kampar Peninsula, Sumatera; however, only 7 NTFPs were used commercially by the local communities. Hence, the economic value of NTFPs was very low. To prevent forest conversion and preserve the peat swamp forest ecosystem's quality, realizing the full economic values of those commercial NTFPs is not enough. To this end, market development of NTFPs is crucial and the government should play an important role in promoting it in collaboration with private companies. But, this commercialization may lead to some undesirable outcomes, such as resource depletion and domination of traders on local market for NTFPs. To minimize the possibility of such perverse outcomes, the commercialization of NTFPs requires some strategies, such as promotion of certification of NTFPs, encouragement of cultivation, strengthening of institutional support and policies to ensure equitable sharing of profits, encouragement of traditional conservation and management practices, and development of enterprises. In addition, the measure of the economic value in tropical peatland ecosystem must take into account non-marketed NTFPs and various environmental service values. 


\section{ACKNOWLEDGEMENTS}

The authors would like to thank Edfan Darlis of the University of Riau, Pekanbaru, Indonesia and Zainuri Hasyim of Yayasan Mitra Insani, Indonesia for their field assistance. This study was partially funded by Greenpeace Southeast Asia and Non-Timber Forest Products-Exchange Programme Indonesia (NTFP-EP Indonesia).

\section{REFERENCES}

Angelsen A, Jagger P, Babigumira R, Belcher B, Hogarth NJ, Bauch S, Borner J, Smith-Hall C, Wunder S. 2014. Environmental income and rural livelihoods: a global comparative analysis. World Dev 64: 1228.

Arnold JEM, Perez MR. 2001. Can non-timber forest products match tropical forest conservation and development objectives?. Ecol Econ 39: 437-447.

Bahruni, Suhendang E, Darusman D, Alikodra HS. 2007. A system approach to estimate total economic value of forest ecosystem: use value of timber and non timber forest products. Jurnal Penelitian Sosial dan Ekonomi Kehutanan 4 (3): 369-378.

Belcher B, Ruiz-Perez M, Achdiawan R. 2005. Global patterns and trends in the use and management of commercial NTFPs: implications for livelihoods and conservation. World Dev 33 (9): 1435-1452.

Dash M, Behera B, Rahut DB. 2016. Determinants of household collection of non-timber forest products (NTFPs) and alternative livelihood activities in Similipal Tiger Reserve, India. For Policy Econ 73: 215-228.

Dawson IK, Leakey R, Clement CR, Weber JC, Cornelius JP, Roshetko JM, Vinceti B, Kalinganire A, Tchoundjeu Z, Masters E, Jamnadass R. 2014. The management of tree genetic resources and the livelihoods of rural communities in the tropics: non-timber forest products, smallholder agroforestry practices and tree commodity crops. For Ecol Manag 333: 9-21.

Delang CO. 2006. Not just minor forest products: the economic rationale for the consumption of wild food plants by subsistence farmers. Ecol Econ 59 (1): 64-73.

Delgado TS, McCall MK, López-Binqüist C. 2016. Recognized but not supported: assessing the incorporation of non-timber forest products into Mexican forest policy. For Policy Econ 71: 36-42.

FAO. 1995. Non-Wood Forest Products for Rural Income and Sustainable Forestry. Food and Agriculture Organization (FAO), Rome.

Ghate R, Mehra D, Nagendra H. 2009. Local institutions as mediators of the impact of markets on non-timber forest product extraction in central India. Environ Conserv 36 (1): 51-61.

Gillet P, Vermeulen C, Doucet JL, Codina E, Lehnebach C, Feintrenie L. 2016. What Are the impacts of deforestation on the harvest of nontimber forest products in Central Africa ?. Forest 7 (12): 1-15.

Godoy R, Overman H, Demmer J, Apaza L, Byron E, Huanca T, Leonard W, Perez E, Reyes-Garcia V, Vadez V, Wilkie D, Cubas A, McSweeney K, Brokaw N. 2002. Local financial benefits of rain forests: comparative evidence from Amerindian societies in Bolivia and Honduras. Ecol Econ 40 (3): 397-409.

Gram. 2001. Economic valuation of special forest products: an assessment of methodological shortcomings. Ecological Economics 36: 109-117. Guariguata MR, Cronkleton P, Shanley P, Taylor PL. 2008. The compatibility of timber and non-timber forest product extraction and management. For Ecol Manag 256: 1477-1481.

Guariguata MR, Garcia-Fernandez C, Sheil D, Nasi R, Herrero-Jauregui C, Cronkleton P, Ingram, V. 2010. Compatibility of timber and nontimber forest product management in natural tropical forests: perspectives, challenges, and opportunities. For Ecol Manag 259: 237-245.

He J, Dong M, Stark M. 2014. Small mushrooms for big business? gaps in the sustainable management of Non-Timber Forest Products in Southwest China. Sustainability 6 (10): 6847-6861.

Heubach K, Wittig R, Nuppenau E, Hahn K. 2011. The economic importance of non-timber forest products (NTFPs) for livelihood maintenance of rural west African communities: a case study from northern Benin. Ecol Econ 70 (11): 1991-2001.
IIED. 2003. Valuing forests: a review of methods and applications in developing countries. Environmental Economics Programme, London.

Institut Pertanian Bogor. 1999. Kajian Sistem Nilai Hutan Produksi. Fakultas Kehutanan, Bogor. [Indonesian]

Janse G, Ottitsch A. 2005. Factors influencing the role of Non-Wood Forest Products and Services. For Policy Econ 7: 309-319.

Kim YC. 2002. Pola Pengelolaan Hutan Tropika berdasar pada Konsep Nilai Ekonomi Total. [Dissertation]. Universitas Gadjah Mada, Yogyakarta. [Indonesian].

Klemperer WD. 1996. Forest Resource Economics and Finance. McGrawHill, Inc., New York.

Krishnakumar J, Yanagida JF, Anitha V, Balakrishnan R, Radovich TJK. 2014. Non-timber forest products certification and management: a socioeconomic study among the Kadars in Kerala, India. Environ Dev Sustain 17 (4): 837-858.

Mahapatra AK, Tewari DD. 2005. Importance of non-timber forest products in the economic valuation of dry deciduous forests of India. For Pol Econ 7: 455-467.

Marshall E, Newton AC, Schreckenberg K. 2003. Commercialisation of non-timber forest products: first steps in analysing the factors influencing success. Intl For Rev 5 (2): 128-137.

Ministry of Environment and Forestry Republic of Indonesia. 2018. The State of Indonesia's Forests 2018. Ministry of Environment and Forestry Republic of Indonesia, Jakarta.

Ndangalasi HJ, Bitariho R, Dovie DBK. 2007. Harvesting of non-timber forest products and implications for conservation in two montane forests of East Africa. Biol Conserv 134 (2): 242-250.

Ren Y, Kuuluvainen J, Toppinen A, Yao S, Berghall S, Karppinen H, Xue C, Yang, L. 2018. The effect of China's new circular collective forest tenure reform on household non-timber forest product production in natural forest protection project regions. Sustainability 10 (4): 1-17.

Riera P, Signorello G, Thiene M, Mahieu P, Navrud S, Kaval P, Rulleau B, Mavsar R, Madureira L, Meyerhoff J, Elsasser P, Nataro S, DeSalvo M, Giergiczny M, Dragoi S. 2012. Non-market valuation of forest goods and services: good practice guidelines. J For Econ 18 (4): 259-270.

Ros-Tonen MAF, Wiersum KF. 2005. The Scope for improving rural livelihoods through non-timber forest products: an evolving research agenda. For Trees Livelihoods 15 (2): 129-148.

Saha D, Sundriyal RC. 2012. Utilization of non-timber forest products in humid tropics: implications for management and livelihood. For Policy Econ 14 (1): 28-40.

Sakai S, Choy YK, Kishimoto-Yamada K, Takano KT, Ichikawa M, Samejima, H, Yumi K, Soda R, Ushio M, Saizen I, Nakashizuka T, Itioka, T. 2016. Social and ecological factors associated with the use of non-timber forest products by people in rural Borneo. Biol Conserv 204: $340-349$.

Salafsky N, Wollenberg E. 2000. Linking livelihoods and conservation: a conceptual framework and scale for assessing the integration of human needs and biodiversity. World Dev 28 (8): 1421-1438.

Schaafsma M, Morse-jones S, Posen P, Swetnam RD, Balmford A, Bateman, IJ, Burgess ND, Chamshama SAO, Fisher B, Freeman T, Geoffrey V, Green RE, Hepelwa AS, Hernandez-sirvent A, Hess S, Kajembe GC, Kayharara G, Kilonzo M, Kulindwa K, Lund JF, Madoffe SS, Mbwambo L, Meilby H, Ngaga YM, Theilade I, Treue T, Van-Beukering P, Vyamana VG, Turner RK. 2014. The importance of local forest benefits: economic valuation of non-timber forest products in the Eastern Arc Mountains in Tanzania. Glob Environ Ch 24: 295-305.

Shackleton CM, Pandey AK. 2014. Positioning non-timber forest products on the development agenda. For Policy Econ 38: 1-7.

Shone BM, Caviglia-Harris JL. 2006. Quantifying and comparing the value of non-timber forest products in the Amazon. Ecol Econ 58: 249-267.

Simangunsong BCH, 2003. The economic value of Indonesia's natural production forest. Indonesian Working Group on Forest Finance, Jakarta.

Simangunsong BCH, Sitanggang VJ, Manurung EGT, Rahmadi A, Moore GA, Aye L, Tambunan AH. 2017. Potential forest biomass resource as feedstock for bioenergy and its economic value in Indonesia. For Policy Econ 81: 10-17.

Stanley D, Voeks R, Short L. 2012. Is non-timber forest products harvest sustainable in the Less Developed World? A systematic review of the recent economic and ecological literature. Ethnobiol Conserv 1 (9): 139. 
Stenger A, Harou P, Navrud S. 2009. Valuing environmental goods and services derived from the forests. J For Econ 15: 1-14.

Tiwari BK, Kumar C, Lynser MB. 2009. The future of non-wood forest production. In Leslie R. N. (eds.), The Future of Forests in Asia and the Pacific: Outlook for 2020, Oct 16-18, 2007, Chiang Mai. FAO, Bangkok.
Tropenbos Indonesia. 2010. Penilaian Kawasan dengan Nilai Konservasi Tinggi di Semenanjung Kampar. Tropenbos Indonesia, Jakarta. [Indonesian]

Yayasan Mitra Insani. 2008. Dokumen potensi Desa Teluk Meranti. www.adoc.tips/dokumen-potensi-desa-teluk-meranti.html [Indonesian] 